\title{
Trends in Attitudes of Whites, Blacks, Asians, and Hispanics toward Intermarriage in the Twenty-First Century
}

\author{
Philip Q. Yang * and Jonbita Prost \\ Department of Sociology, Texas Woman's University, Denton, TX 76204, USA; jprost@twu.edu \\ * Correspondence: pyang@twu.edu
}

check for updates

Citation: Yang, P.Q.; Prost, J. Trends in Attitudes of Whites, Blacks, Asians, and Hispanics toward Intermarriage in the Twenty-First Century. Societies 2021, 11, 21. https://doi.org/ $10.3390 / \operatorname{soc} 11010021$

Academic Editor: Salvatore Palidda

Received: 21 December 2020

Accepted: 8 March 2021

Published: 12 March 2021

Publisher's Note: MDPI stays neutral with regard to jurisdictional claims in published maps and institutional affiliations.

Copyright: (c) 2021 by the authors. Licensee MDPI, Basel, Switzerland. This article is an open access article distributed under the terms and conditions of the Creative Commons Attribution (CC BY) license (https:// creativecommons.org/licenses/by/ $4.0 /)$.

\begin{abstract}
No study has simultaneously compared attitudes of whites, blacks, Asians, and Hispanics toward intermarriage over time. This study offers a comparative analysis of the changes in attitudes of whites, blacks, Asians, and Hispanics toward intermarriage with different racial or ethnic groups in the twenty-first century, using nationally representative samples from General Social Surveys 2000-2018. Our trend analyses reveal that whites' support for intermarriage with minorities has generally increased, albeit at a relatively lower level; blacks' support for intermarriage with Asians, Hispanics, and whites has been quite stable at a relatively high level; Asians' and Hispanics' support for intermarriage with other minorities has generally shown an upswing trend with some minor fluctuations, but their support for intermarriage with whites has gone in the opposite direction with oscillations. The results of our generalized linear ordinal logistic regression models show that either including or excluding control variables, whites' attitudes have become generally more supportive of intermarriage with minorities, blacks' support for intermarriage has displayed an undulated pattern, and Asians' and Hispanics' support for intermarriage reveal diverse patterns depending on the group to intermarry with. The findings indicate a general trend of narrowing intergroup social distances as well as some increases in social distance between certain groups in the United States in the twenty-first century.
\end{abstract}

Keywords: trends; attitudes; intermarriage; whites; blacks; Asians; Hispanics; twenty-first century

\section{Introduction}

Intermarriage is an integral part of assimilation and a barometer of social integration and social distance [1,2]. Attitudes toward intermarriage also reflect intergroup social distance, social acceptance, and social progress. There are quite a few studies of attitudes toward interracial marriage between blacks and whites, typically with a cross-sectional design, oftentimes focusing on whites' attitudes and sometimes including blacks' attitudes [3-9]. However, comparative studies of attitudes of whites, blacks, Asians, and Hispanics toward intermarriage with different racial or ethnic groups are lacking. A simultaneous comparison of attitudes of whites, blacks, Asians, and Hispanics toward intermarriage with different groups in the twenty-first century will help reveal the current intergroup social distance, social acceptance, and social progress in the United States. There are opinion polls and reports that provide some statistics about public attitudes toward intermarriage to different groups [10-13]. Nevertheless, the results are not differentiated by race or ethnicity, and they typically do not control for other factors that also influence such attitudes toward intermarriage and therefore may not provide accurate estimates.

To fill these gaps in the literature, this study compares changes in attitudes of whites, blacks, Asians, and Hispanics toward intermarriage in the twenty-first century, using the latest General Social Surveys (GSS) 2000-2018. We define intermarriage as a marriage between a person of a racial or ethnic group and a member of a different racial or ethnic group. In this study, race or ethnicity is based on the self-identification of the respondents. Intermarriage includes both interracial marriage and interethnic marriage. We prefer 
the broader term intermarriage to interracial marriage because Hispanic is recognized by the U.S. government as an ethnic group but not a racial group. Our study assesses the changes with and without the control of other potential determinants of attitudes toward intermarriage. In the sections that follow, we briefly review the relevant literature, propose our hypothesis, depict our data and methods, present our findings, and discuss the implications of the findings.

\section{Literature Review}

Prior to the Supreme Court ruling on Loving v. Virginia in 1967, interracial marriage in the United States was quite limited because anti-miscegenation laws banned interracial marriage in many states $[14,15]$. The ruling on Loving $v$. Virginia repealed the unconstitutional anti-miscegenation laws and paved the way for the growing acceptance of intermarriage. Since 1967, the intermarriage rate increased from 3\% in 1967 to $17 \%$ in 2015 for newlyweds and from 3\% in 1980 to $10 \%$ in 2015 for all married people [11]. The increases in intermarriage rates were most dramatic among black newlyweds from $5 \%$ in 1980 to $18 \%$ in 2015 and among white newlyweds from 4\% in 1980 to $11 \%$ in 2015, although Asian and Hispanic newlyweds were far more likely to intermarry than their black and white counterparts [11].

Concomitant with the growth of intermarriages, attitudes toward intermarriage have become more tolerant as shown in the literature. There are quite a few studies of whites' attitudes toward intermarriage $[4,5,7,8,16]$. It is well documented that whites' approval of intermarriage has been increasing $[10,16,17]$, but these results do not control for other determinants of attitudes toward intermarriage. Studies that use multivariate techniques $[4,5,7,8]$ tended to use a cross-sectional design and data in 2000 or a little later. A few studies examine blacks' attitudes toward intermarriage [3,6,10,17]. These studies also reported that blacks' approval of black-white intermarriage has been on the rise and a higher percentage of blacks approved black-white intermarriage than whites. Nonetheless, they are mostly descriptive or bivariate analyses and used a small sample or data in 2000 or before, except for Djamba and Kimuna's study [3]. To our knowledge, there is no stand-alone study of Asians' or Hispanics' attitudes toward intermarriage, but some statistics about Hispanics' attitudes toward intermarriage can be found from a couple of reports $[10,13]$. For instance, Gallup polls showed that support for intermarriage between blacks and whites among Hispanics increased modestly from $84 \%$ in 2002 to $87 \%$ in 2007 [10]. A report by PEW Research Center based on a survey in 2009 [13] found that Hispanics favored intermarriage with whites (81\%), then with Asians (76\%), and then with blacks (73\%).

Moreover, to the best of our knowledge, no single study has systematically analyzed the attitudes of whites, blacks, Asians, and Hispanics toward intermarriage with various racial or ethnic groups simultaneously, much less using longitudinal data. It is important to compare attitudes of multiple racial or ethnic groups toward intermarriage concurrently for the same period of time because such a study can help assess the extent to which these groups are accepted and whether social distance between groups is decreasing [8]. There is a linkage between support for intermarriage and harmonious intergroup relations. A better understanding of the factors conducive to the support for intermarriage can facilitate amicable intergroup relations $[7,8,18]$.

\section{Hypothesis}

Our hypothesis is that, in the twenty-first century, different racial or ethnic groups of Americans should all have become more tolerant toward intermarriage with other racial or ethnic minorities over time, either controlling or not controlling for other determinants of attitudes toward intermarriages, but different racial or ethnic groups are likely to show different patterns of attitudes toward intermarriage with different groups. Our expectation of uniform progress toward intermarriage with outgroups is based on the impact of increasing educational attainment and growing racial and ethnic diversity in American society on intermarriage and attitudes toward intermarriage. Existing studies [19-22] have 
demonstrated the key role of educational attainment in changing patterns of intermarriage. For Asians and Hispanics, as a force of breaking racial or ethnic barriers, educational attainment has been shown to be positively associated with intermarriage with whites although the effect of education on blacks' intermarriage with whites is weaker $[20,21,23]$. Meanwhile, as the U.S. population becomes more educated, it tends to become more open minded and more tolerant toward intermarriage with outgroups in attitudes [13]. Under certain conditions, changing demographic landscape also increases intergroup contacts, reduces prejudices, and decreases social distance, thereby leading to the increasing acceptance of intermarriage with other groups [24-26].

On the other hand, the degree of accepting intermarriage with outgroups can be expected to vary across different groups for a number of reasons. First, varying degrees of prejudices against, and stereotypes about, minority groups (e.g., blacks) across racial or ethnic groups are very likely to engender social distances between groups and the group to intermarry with, leading to cross-group variations in the acceptance of intermarriage. Second, because of the historical and contemporary experiences of discrimination and shared common interests, minority groups may have a sense of affinity toward other minority groups but a sense of alienation toward whites, which may contribute to variations in support for intermarriage with minority groups and whites. Third, nativity could be another contributing factor. Whites and blacks are overwhelmingly U.S.-born, but a high proportion of Hispanics are foreign-born, and Asians are largely foreign-born [27]. Since the native-born and the foreign-born may see things in different perspectives, it is not surprising that groups with different nativity statuses may have various preferences for the groups to intermarry with.

\section{Data and Methods}

\subsection{Data and Samples}

The data for this study come from GSS 2000-2018 [28]. The GSS is one of the best sources of data on attitudes toward intermarriage over time. Administered by the National Opinion Research Center (NORC) at the University of Chicago, the GSS has conducted surveys of non-institutionalized U.S. adult population aged 18 or older since 1972, first annually (except for 1979 and 1981) and then biannually since 1994. Before 2006, only English-speaking adults were surveyed, but since 2006 Spanish interviews have been conducted, so both English and Spanish speakers have been part of the target population. Between 1972 and 2000, the survey was administered in a paper-and-pencil format, but since 2002 the survey has been conducted by computer-assisted personal interview. The 1972-1974 GSSs followed a modified probability sampling design and the 1975-1976 GSSs used a transitional design. However, since 1977, the GSS has generated full probability samples based on a multistage probability sampling design. We weighted the data by the weight variable created and recommended by the NORC based on a complex weighting process in order to represent the actual population [28]. In so doing, our findings can be generalized to the U.S. adult population.

We limited our analysis to the period of 2000-2018 for three reasons. One is to facilitate cross-group comparison with similar years. While data on attitudes toward intermarriage with blacks were also available for 1990, 1996, and 1998, data on attitudes toward intermarriage with Asians and Hispanics were only available for 1990, and no data on intermarriage with whites were available prior to 2000. The second consideration is that the GSS will not allow extracting a separate Asian or Hispanic sample prior to 2000 as Asians and Hispanics were lumped under the category of other race. The last consideration is to focus on the newest trends in attitudes toward intermarriage in the twenty-first century.

We divided GSS 2000-2018 into four broad samples: whites, blacks, Asians, and Hispanics. We only considered attitudes toward intermarriage with outgroups but not with one's own group (the so-called intra-marriage). Within each broad sample, we restricted the analysis to the valid cases of the dependent variables on attitudes toward intermarriage 
with blacks, Asians, Hispanics, and whites, as appropriate. The restricted white samples contain 10,963 cases for attitudes toward intermarriage with blacks, 9340 cases for attitudes toward intermarriage with Asians, and 9352 cases for attitudes toward intermarriage with Hispanics. The restricted black samples contain 1593 cases for attitudes toward intermarriage with Asians, 1595 cases for attitudes toward intermarriage with Hispanics, and 1773 cases for attitudes toward intermarriage with whites. The restricted Asian samples contain 479 cases for attitudes toward intermarriage with blacks, 454 cases for attitudes toward intermarriage with Hispanics, and 482 cases for attitudes toward intermarriage with whites. The restricted Hispanic samples contain 612 cases for attitudes toward intermarriage with blacks, 588 cases for attitudes toward intermarriage with Asians, and 614 cases for attitudes toward intermarriage with whites.

One limitation with the data is that the GSS did not ask questions regarding intermarriage with Asians and Hispanics in 2002. Another limitation is that continuous data every year would be ideal, but the GSS has only collected data every other year since 1994. The third limitation is that the sample sizes of Asians and Hispanics are modest and therefore decrease the likelihood of obtaining statistically significant estimates. Finally, the income variable contains a significant number of missing cases, so we decided not to include it in the final presentation. These limitations notwithstanding, the GSS remains the best available data to perform a comparative analysis of attitudes of whites, blacks, Asians, and Hispanics toward intermarriage with different racial or ethnic groups.

\subsection{Dependent Variables}

The dependent variables for this study include support for intermarriage with blacks, support for intermarriage with Asians, support for intermarriage with Hispanics, and support for intermarriage with whites. These variables are based on such a question as "What about having a close relative marry a black person [an Asian American person/a Hispanic American person/a white person]? Would you be very in favor of it happening, somewhat in favor, neither in favor nor opposed to it happening, somewhat opposed, or very opposed to it happening?" Each of these dependent variables is measured by an ordinal scale with five categories: strongly favor $=1$, favor $=2$, neither favor nor oppose $=$ 3 , oppose $=4$, and strongly oppose $=5$. We reverse coded each of these variables, so that a higher value indicates a higher level of support. It is clear that these variables measure attitudes toward intermarriage rather than intermarriage per se.

\subsection{Independent Variable}

The main independent variable is year. To test the possible nonlinear and fluctuating effects of year on the dependent variables, we created nine dummy variables for years coded 1 for the designated year (e.g., year $2018=1$ ) and coded 0 otherwise, with year 2000 as the reference category.

\subsection{Control Variables}

To test the effect of year on the dependent variables, we must control for other variables that could potentially affect attitudes toward intermarriage with blacks, Asians, Hispanics, and whites. In light of the evidence in the literature or theorization [3,5-9,11,13,25], we control for the following variables: age, sex, marital status, region, religion, education, political party affiliation, and political orientation. Age is a continuous variable ranging from 18 to 89 or older. Sex is a dummy variable coded 1 for female and coded 0 for male. Marital status is a dummy variable coded 1 for currently married and coded 0 for not currently married. Region is measured by three dummy variables: Northeast $($ Northeast $=1$, else $=0)$, Midwest (Midwest $=1$, else $=0)$, and West $($ West $=1$, else $=0$ ) with South as the reference category. Religion is measured by a dummy variable Christian $($ Christian $=1$, non-Christian $=0)$. Education is a continuous variable with a range of 0 to 20 or more years of schooling. We created one dummy variable for Republican with 1 for the designated category and 0 otherwise. Political conservatism is an ordinal scale with 
seven categories $(1=$ extremely liberal, $2=$ liberal, $3=$ slightly liberal, $4=$ moderate, $5=$ slightly conservative, $6=$ conservative, and $7=$ extremely conservative).

\subsection{Methods and Analytical Strategies}

We first calculated descriptive statistics of the four dependent variables by racial or ethnic category (i.e., whites, blacks, Asians, and Hispanics) and of the predictor variables (not shown to avoid too many tables). We then did trend analyses by year for each of the dependent variables for each of the four racial or ethnic categories. Since the dependent variables are ordinal variables, we used the generalized linear model (GLM) in SPSS, specifically generalized linear ordinal logistic regression model, with robust estimator for the covariance matrix. We tested two GLM models for each dependent variable for each racial or ethnic category. Model 1 includes dummy variables for years 2000-2018, with year 2000 as the reference category, and Model 2 adds control variables to Model 1.

\section{Results}

\subsection{Descriptive Analysis}

Table 1 presents the means and standard deviations of the dependent variables by race or ethnicity for the entire period of 2000 to 2018. The means for the white sample indicate that on average whites favored intermarriage with Hispanics the most (3.279), followed by Asians (3.260), and blacks (3.050). In descending order, blacks on average favored intermarriage with whites, Hispanics, and Asians; Asians on average favored intermarriage with whites, Hispanics, and blacks; and Hispanics on average favored intermarriage with whites, Asians, and blacks. Reading the table column by column, one can see that for support for intermarriage with blacks, Hispanics had the highest mean (3.437), and for support for intermarriage with whites, Hispanics, and Asians, blacks had the highest means.

Table 1. Means and Standard Deviations (SD) of Support for Intermarriage with Whites, Blacks, Asians, and Hispanics by Race/Ethnicity, GSS 2000-2018.

\begin{tabular}{|c|c|c|c|c|c|c|c|c|}
\hline \multirow{2}{*}{ Variable } & \multicolumn{2}{|c|}{$\begin{array}{c}\text { Intermarriage with } \\
\text { Whites }\end{array}$} & \multicolumn{2}{|c|}{$\begin{array}{c}\text { Intermarriage with } \\
\text { Blacks }\end{array}$} & \multicolumn{2}{|c|}{$\begin{array}{c}\text { Intermarriage with } \\
\text { Asians }\end{array}$} & \multicolumn{2}{|c|}{$\begin{array}{c}\text { Intermarriage with } \\
\text { Hispanics }\end{array}$} \\
\hline & Mean & SD & Mean & SD & Mean & SD & Mean & SD \\
\hline $\begin{array}{l}\text { Whites' support for } \\
\text { intermarriage }\end{array}$ & - & - & 3.050 & 1.134 & 3.260 & 1.004 & 3.279 & 1.022 \\
\hline $\begin{array}{l}\text { Blacks' support } \\
\text { for intermarriage }\end{array}$ & 3.742 & 1.061 & - & - & 3.667 & 1.061 & 3.694 & 1.050 \\
\hline $\begin{array}{l}\text { Asians' support } \\
\text { for intermarriage }\end{array}$ & 3.484 & 0.929 & 3.121 & 1.006 & - & - & 3.306 & 0.944 \\
\hline $\begin{array}{l}\text { Hispanics' support for } \\
\text { intermarriage }\end{array}$ & 3.683 & 0.932 & 3.437 & 1.053 & 3.550 & 0.947 & - & - \\
\hline
\end{tabular}

\subsection{Trend Analyses}

Figure 1 shows changes in attitudes toward intermarriage with whites, blacks, Asians, and Hispanics by race or ethnicity from 2000 to 2018, including the means and their 95\% confidence intervals (CI). Panel A reveals that whites' average level of support for intermarriage with blacks, Asians, and Hispanics had gradually increased from 2000 to 2018 with some minor fluctuations, but the levels of support were always below 3.5. Also notice that the levels of support for intermarriage with Asians and Hispanics were always higher than that for intermarriage with blacks. The margins of errors for the mean estimates were very small as indicated by the very narrow $95 \%$ CIs because of the substantial sample sizes. Panel B displays that except for oscillations in 2000 and 2004, blacks' support for intermarriage with whites, Asians, and Hispanics had stayed quite stable at a level above 3.5 and close to the level of favor (4) and converged. The 95\% CIs showed somewhat 
greater margins of errors for the means, especially for 2000-2004, in comparison with those in Panel A. Panel C exhibits that Asians' support for intermarriage with whites had overall declined from $3.73(95 \%$ CIs $=3.384,4.076)$ in 2000 to $3.43(95 \%$ CIs $=3.083,3.777)$ in 2018 with fluctuations, but Asians' support for intermarriage with blacks first decreased and then gradually climbed in more recent years, and Asians' support for intermarriage with Hispanics first declined and then gradually increased back to about the 2000 level in more recent years. The margins of errors for the means appeared to be bigger than those in Panels A and B because of the significantly smaller sample sizes, but the general patterns did not change. Panel D shows that Hispanics' support for intermarriage with blacks and Asians has been increasing with some minor fluctuations, but Hispanics' support for intermarriage with whites had overall declined from $4.03(95 \%$ CIs $=3.720,4.340)$ in 2000 to $3.69(95 \%$ CIs $=3.496,3.884)$ in 2018 with oscillations. Due to the modest sample sizes, the $95 \%$ CIs also displayed greater margins of errors for the means, especially before 2006, compared with those in Panels A and B, but the patterns remained unchanged.
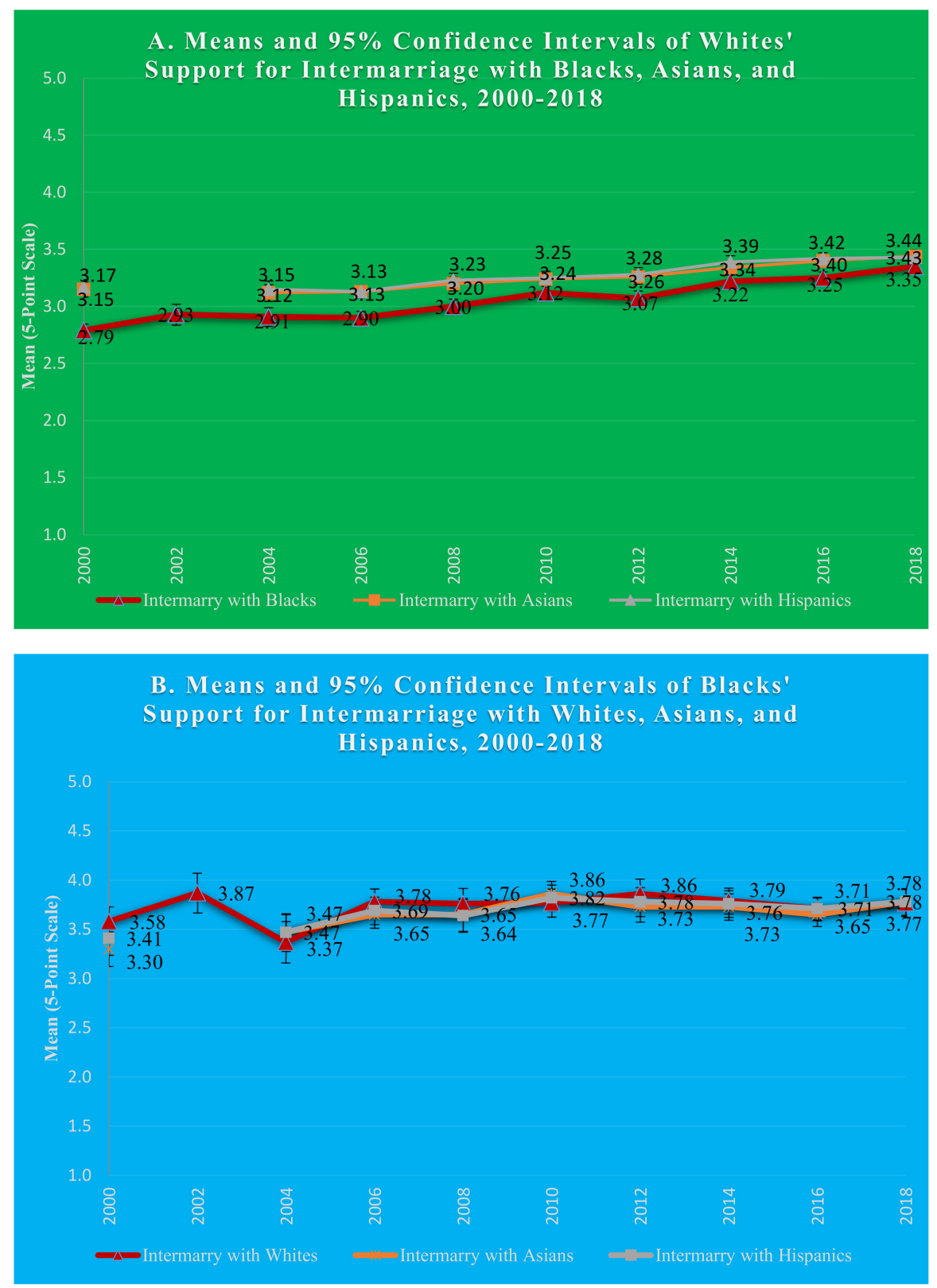

Figure 1. Cont. 

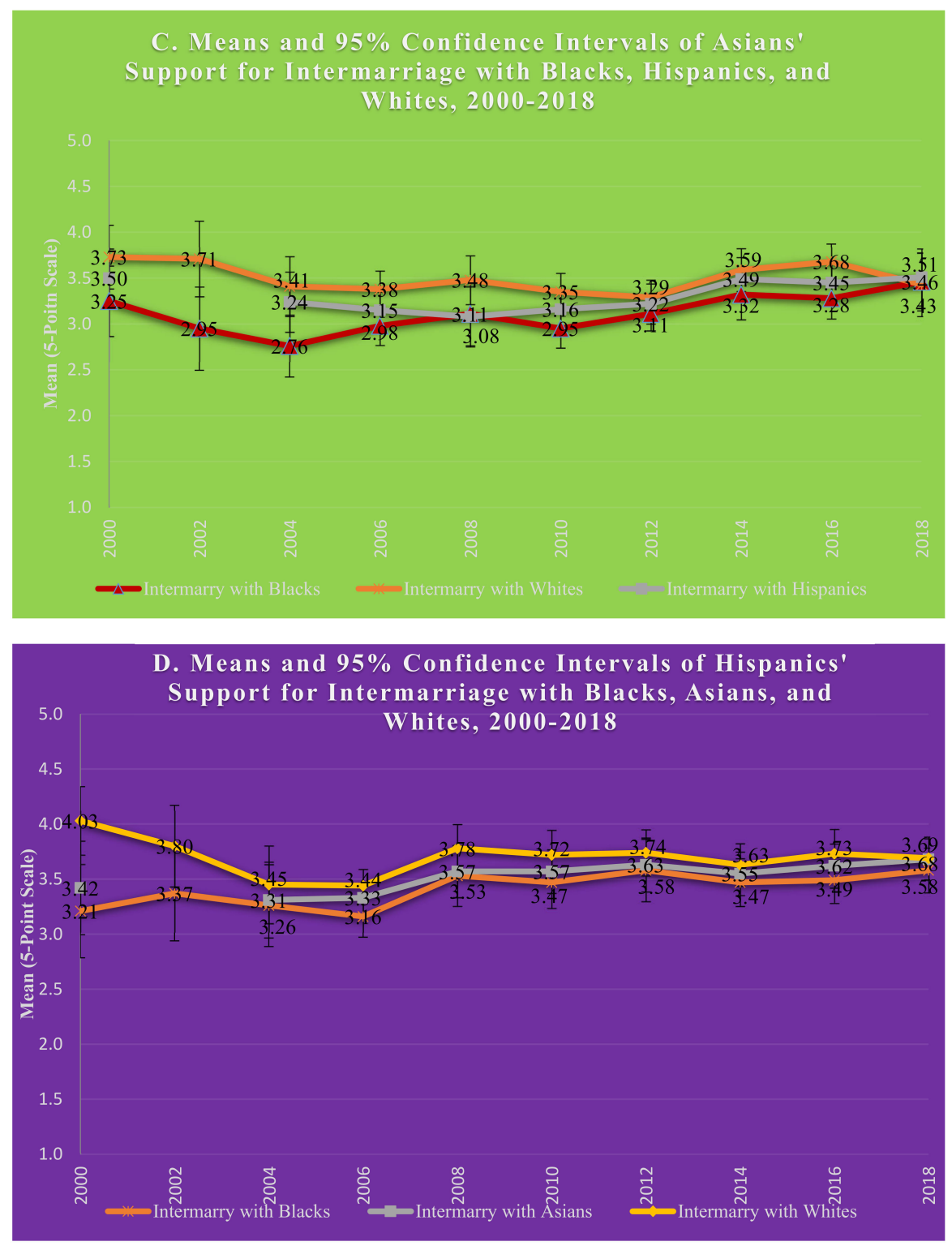

Figure 1. Trends in Attitudes of Whites, Blacks, Asians, and Hispanics toward Intermarriage, 2000-2018.

The overall picture reveals very diverse patterns in support for intermarriage across racial or ethnic groups. Whites have become much more tolerant toward intermarriage with minority groups. This pattern is not very likely due to sampling errors as indicated by the very small margins of errors shown by the $95 \%$ CIs. Blacks showed consistently high levels of support for intermarriage with all other groups. While Asians' and Hispanics' support for intermarriage with blacks generally followed an upswing trend, their support for intermarriage with whites headed in the opposite direction. By and large, the levels of minorities' support for intermarriage were higher than that of whites'. These results are generally consistent with our hypothesis. Nevertheless, these results have not taken into account other factors that could potentially influence attitudes toward intermarriages. To control for other determinants of attitudes toward intermarriages, multiple regression is called for.

\subsection{Generalized Linear Ordinal Logistic Regression Analyses}

We conducted four sets of generalized linear ordinal logistic regression analyses of support for intermarriage with different groups by race or ethnicity. There is no multicollinearity problem. For each racial or ethnic group and for each dependent variable, we 
tested two models. Model 1 includes dummy variables for years, and Model 2 adds the control variables to Model 1 to test if the patterns observed in Model 1 change after other predictors are held constant. We present the results of changes in support for intermarriage by race or ethnicity below.

\subsubsection{Changes in Whites' Support for Intermarriage with Minorities}

Table 2 presents the results of whites' support for intermarriage with blacks, Asians, and Hispanics over time. For each of the three dependent variables, Model 2 fits the data better than Model 1 because the difference in likelihood ratio $\chi^{2}$ between Model 2 and Model 1 is significant given the difference of 10 or 11 degrees of freedom. Beginning with whites' attitudes toward intermarriage with blacks, Model 1 shows that the likelihood ratio $\chi^{2}(=289)$ is highly significant at the 0.001 level, indicating that Model 1 is a good model. All the odds ratios for the year dummy variables are greater than 1 with generally increasing magnitudes and significant at least at the 0.05 level, indicating that, compared to the white respondents in year 2000, the white respondents in later years were significantly more supportive of intermarriage with blacks. For example, the respondents in 2002 were 1.231 times as likely as the respondents in 2000 to have a more supportive attitude toward intermarriage with blacks (odds ratio $=1.231$ ), and the respondents in 2018 were 2.531 times as likely as the respondents in 2000 to have a more supportive attitude toward intermarriage with blacks (odds ratio $=2.531$ ). The overall trend was increasing support for intermarriage with blacks, especially since 2014. The likelihood ratio $\chi^{2}$ of Model $2(=1461)$ is much greater than that of Model 1, indicating a better fit of Model 2 than Model 1. As shown in Model 2, the inclusion of control variables did not change the trend observed in Model 1. The magnitudes of the odds ratios for the year dummy variables are greater in later years with some fluctuations. These results lend support to our hypothesis pertinent to whites' attitudes toward intermarriage with blacks.

Moving on to whites' attitudes toward intermarriage with Asians, we can see from both Models 1 and 2 that, except for 2004, 2006, 2008, and 2012 that were not significantly different from 2000, whites' support for intermarriage with Asians has generally increased year by year, with or without the control variables. Generally, the later the year, the greater the support for intermarriage with Asians. These results coincide with our hypothesis germane to whites' attitudes toward intermarriage with Asians.

With regard to whites' attitudes toward intermarriage with Hispanics, both Models 1 and 2 show that the white respondents in 2004,2006, 2008, and 2012 were not significantly different from the whites respondents in 2000, but generally the later the year, the greater the support for intermarriage with Hispanics. Especially, support for intermarriage with Hispanics tended to grow since 2010. This may be due to positive changes in attitudes toward Hispanics in more recent years. These results are consistent with our hypothesis relevant to whites' attitudes toward intermarriage with Hispanics.

Table 2 also shows that older whites were significantly less likely to support intermarriage with blacks, Asians, and Hispanics than younger whites. White women were uniformly more likely to support intermarriage with blacks, Asians, and Hispanics than white men. Marital status has no significant effect on support for intermarriage with any group. Whites in the Northeast, Midwest, and West were more likely to support intermarriage with blacks, Asians, and Hispanics than whites in the South. Education was significantly and positively correlated with whites' support for intermarriage with blacks, Asians, and Hispanics. There was no significant difference between white Christians and white non-Christians in support for intermarriage with blacks, Asians, and Hispanics. White Republicans were less likely to support intermarriage with minorities than white non-Republicans, but the difference was only significant for support for intermarriage with blacks and Hispanics but not with Asians. Political conservatism was significantly and negatively correlated with support for intermarriage with blacks, Asians, and Hispanics. 
Table 2. Odds Ratios of Generalized Linear Ordinal Logistic Regression Models Predicting Whites' Support for Intermarriages with Blacks, Asians, and Hispanics, GSS 2000-2018.

\begin{tabular}{|c|c|c|c|c|c|c|}
\hline \multirow{2}{*}{ Predictor } & \multicolumn{2}{|c|}{ Intermarriage with Blacks } & \multicolumn{2}{|c|}{ Intermarriage with Asians } & \multicolumn{2}{|c|}{ Intermarriage with Hispanics } \\
\hline & Model 1 & Model 2 & Model 1 & Model 2 & Model 1 & Model 2 \\
\hline Threshold 1 & $0.206^{* * *}$ & $0.140^{* * *}$ & $0.065^{* * *}$ & $0.074^{* * *}$ & $0.067^{* * *}$ & $0.067^{* * *}$ \\
\hline Threshold 2 & $0.500^{* * *}$ & $0.381^{* * *}$ & $0.211^{* * *}$ & $0.261^{* * *}$ & $0.213^{* * *}$ & $0.232^{* * *}$ \\
\hline Threshold 3 & $4.420^{* * *}$ & $4.059^{* * *}$ & $2.788^{* * *}$ & $3.764^{* * *}$ & $2.638^{* * *}$ & $3.110^{* * *}$ \\
\hline Threshold 4 & $9.902^{* * *}$ & $9.328^{* * *}$ & $6.667^{* * *}$ & $9.094^{* * *}$ & $6.103^{* * *}$ & $7.296^{* * *}$ \\
\hline \multicolumn{7}{|l|}{ Year $($ Ref.=2000) } \\
\hline 2002 & $1.231 *$ & $1.217^{*}$ & & & & \\
\hline 2004 & $1.225 *$ & $1.218 *$ & 0.937 & 0.952 & 0.953 & 0.963 \\
\hline 2006 & $1.248^{* *}$ & $1.278^{* * *}$ & 0.935 & 0.979 & 0.896 & 0.948 \\
\hline 2008 & $1.429^{* * *}$ & $1.524^{* * *}$ & 1.021 & 1.081 & 1.068 & 1.114 \\
\hline 2010 & $1.812^{* * *}$ & $1.933^{* * *}$ & 1.201 * & $1.278^{* *}$ & $1.202 *$ & $1.282^{* *}$ \\
\hline 2012 & $1.611^{* * *}$ & $1.567^{* * *}$ & 1.153 & 1.171 & 1.157 & 1.129 \\
\hline 2014 & $2.114^{* * *}$ & $2.241^{* * *}$ & $1.425^{* * *}$ & $1.468^{* * *}$ & $1.485^{* * *}$ & $1.540^{* * *}$ \\
\hline 2016 & $2.146^{* * *}$ & $2.247^{* * *}$ & $1.545^{* * *}$ & $1.608^{* * *}$ & $1.538^{* * *}$ & $1.620^{* * *}$ \\
\hline 2018 & $2.531^{* * *}$ & $2.830^{* * *}$ & $1.617^{* * *}$ & $1.739 * * *$ & $1.519^{* * *}$ & $1.642^{* * *}$ \\
\hline Age & & $0.975^{* * *}$ & & $0.988^{* * *}$ & & $0.989^{* * *}$ \\
\hline Female & & $1.450^{* * *}$ & & $1.388^{* * *}$ & & $1.363^{* * *}$ \\
\hline $\begin{array}{l}\text { Currently } \\
\text { married }\end{array}$ & & 1.003 & & 0.966 & & 0.948 \\
\hline \multicolumn{7}{|l|}{ Region(Ref.=South) } \\
\hline Northeast & & $1.532^{* * *}$ & & $1.241^{* * *}$ & & $1.220 * *$ \\
\hline Midwest & & $1.499^{* * *}$ & & $1.268^{* * *}$ & & $1.241^{* * *}$ \\
\hline West & & $2.030^{* * *}$ & & $1.502^{* * *}$ & & $1.635^{* * *}$ \\
\hline Years of schooling & & $1.070^{* * *}$ & & $1.056^{* * *}$ & & $1.044^{* * *}$ \\
\hline Christian & & 0.969 & & 0.944 & & 1.020 \\
\hline Republican & & $0.850^{* * *}$ & & 0.941 & & $0.903 *$ \\
\hline Conservatism & & $0.899^{* * *}$ & & $0.952 * *$ & & $0.937^{* * *}$ \\
\hline \multicolumn{7}{|l|}{ Likelihood ratio } \\
\hline$x^{2}$ & $289^{* * *}$ & $1461^{* * *}$ & $105^{* * *}$ & $452^{* * *}$ & $105^{* * *}$ & $450^{* * *}$ \\
\hline $\mathrm{df}$ & 8 & 19 & 8 & 18 & 8 & 18 \\
\hline $\mathrm{N}$ & 10,963 & 10,963 & 9340 & 9340 & 9352 & 8971 \\
\hline
\end{tabular}

${ }^{*} P \leq 0.05,{ }^{* *} P \leq 0.01,{ }^{* * *} P \leq 0.001$ (one-tailed test).

\subsubsection{Changes in Blacks' Support for Intermarriage}

Table 3 displays the results of three generalized linear ordinal logistic regression models predicting blacks' support for intermarriage with Asians, Hispanics and whites. For each of the three dependent variables, Model 2 fits the data better than Model 1 because the difference in likelihood ratio $\chi^{2}$ between Model 2 and Model 1 is significant given the difference of 10 degrees of freedom. Hence, our interpretations focus on Model 2. For the effect of year on support for intermarriage, the patterns for both Models 1 and 2 are basically the same except for the significance levels of a few odds ratios for intermarriage with whites. As shown in Models 1 and 2, blacks' support for intermarriage with Asians revealed a waved pattern, but blacks in later years were significantly more likely to support intermarriage with Asians than blacks in 2000, except for those in 2004. Similarly, blacks support for intermarriage with Hispanics also displayed an ebb and flow pattern, but blacks in later years were generally more likely to support intermarriage with Hispanics than blacks in 2000, although the three dummy variables for years 2004, 2008, and 2016 were insignificant at the 0.05 level. We can also see an up and down pattern in blacks support for intermarriage with whites over time, but six year dummy variables were not significantly different from the reference category in 2000 (see Model 2). 
Table 3. Odds Ratios of Generalized Linear Ordinal Logistic Regression Models Predicting Blacks' Support for Intermarriages with Asians, Hispanics, and Whites, GSS 2000-2018.

\begin{tabular}{|c|c|c|c|c|c|c|}
\hline \multirow{2}{*}{ Predictor } & \multicolumn{2}{|c|}{ Intermarriage with Asians } & \multicolumn{2}{|c|}{ Intermarriage with Hispanics } & \multicolumn{2}{|c|}{ Intermarriage with Whites } \\
\hline & Model 1 & Model 2 & Model 1 & Model 2 & Model 1 & Model 2 \\
\hline Threshold 1 & $0.061^{* * *}$ & $0.063^{* * *}$ & $0.053^{* * *}$ & $0.056^{* * *}$ & $0.038^{* * *}$ & $0.024^{* * *}$ \\
\hline Threshold 2 & $0.170^{* * *}$ & $0.181^{* * *}$ & $0.118^{* * *}$ & $0.131^{* * *}$ & $0.110^{* * *}$ & $0.069^{* * *}$ \\
\hline Threshold 3 & $1.927^{* * *}$ & $2.123 *$ & $1.492 * *$ & 1.675 & 1.259 & 0.835 \\
\hline Threshold 4 & $4.257^{* * *}$ & $4.792 * * *$ & $3.406^{* * *}$ & $3.925^{* * *}$ & $2.671^{* * *}$ & 1.837 \\
\hline \multicolumn{7}{|l|}{ Year $($ Ref. $=2000)$} \\
\hline 2002 & & & & & $1.732^{* *}$ & $1.630 *$ \\
\hline 2004 & 1.315 & 1.249 & 1.036 & 1.002 & 0.710 & $0.570 *$ \\
\hline 2006 & $1.825^{* *}$ & $1.746^{* *}$ & $1.565 *$ & 1.524 * & 1.530 * & 1.395 \\
\hline 2008 & $1.890 * *$ & $1.810^{* *}$ & 1.420 & 1.394 & 1.419 & 1.298 \\
\hline 2010 & $2.478^{* * *}$ & $2.333^{* * *}$ & $1.799 * *$ & $1.703^{* *}$ & 1.391 & 1.268 \\
\hline 2012 & $1.848^{* *}$ & $1.832 * *$ & $1.578 *$ & $1.589 *$ & $1.566^{*}$ & $1.536 *$ \\
\hline 2014 & $1.949^{* * *}$ & $2.006^{* * *}$ & $1.729 * *$ & $1.830 * *$ & 1.443 * & 1.406 \\
\hline 2016 & $1.566 *$ & $1.493 *$ & 1.322 & 1.289 & 1.134 & 1.052 \\
\hline 2018 & $2.113^{* * *}$ & $2.327^{* * *}$ & $1.674^{* *}$ & $1.883^{* *}$ & 1.327 & 1.439 \\
\hline Age & & $0.989 * *$ & & $0.989^{* *}$ & & $0.991^{* *}$ \\
\hline Female & & 1.123 & & 1.010 & & $1.291^{* *}$ \\
\hline $\begin{array}{l}\text { Currently } \\
\text { married }\end{array}$ & & 1.039 & & 0.980 & & 1.068 \\
\hline \multicolumn{7}{|l|}{ Region $($ Ref. $=$ South) } \\
\hline Northeast & & 0.771 & & 0.926 & & 0.770 * \\
\hline Midwest & & 1.283 & & 1.262 & & $1.432 * *$ \\
\hline West & & 1.003 & & 1.198 & & 0.896 \\
\hline Years of schooling & & 1.013 & & 1.001 & & 0.970 \\
\hline Christian & & $1.306^{*}$ & & $1.573^{* * *}$ & & $1.505^{* *}$ \\
\hline Republican & & 0.995 & & 0.936 & & 1.514 \\
\hline Conservatism & & 1.032 & & 1.049 & & 0.981 \\
\hline \multicolumn{7}{|l|}{ Likelihood ratio } \\
\hline$x^{2}$ & $30^{* * *}$ & $51^{* * *}$ & $18^{* * *}$ & $42^{* * *}$ & $23^{* *}$ & $71^{* * *}$ \\
\hline $\mathrm{df}$ & 8 & 18 & 8 & 18 & 9 & 19 \\
\hline $\mathrm{N}$ & 1593 & 1494 & 1595 & 1494 & 1773 & 1647 \\
\hline
\end{tabular}

It is also evident from Table 3 that similar to whites, older blacks were significantly less likely to support intermarriage with any outgroup than younger blacks. Black women were somewhat more likely than black men to support intermarriage, but the difference was only significant in support for intermarriage with whites. Marital status made no difference in support for intermarriage with any group. Regional differences were not significant in support for intermarriage with Asians and Hispanics but significant in support for intermarriage with whites. Surprisingly, education had no significant impact on blacks' support for intermarriage with any group. Black Christians were more likely to support intermarriage than black non-Christians. Party affiliation and ideological orientation had no significant effect on blacks' support for intermarriage with any group.

\subsubsection{Changes in Asians' Support for Intermarriage}

The results of three generalized linear ordinal logistic regression models predicting Asians' support for intermarriage with blacks, Hispanics and whites are shown in Table 4. For each of the three dependent variables, Model 2 is a better-fitting model than Model 1 because the difference in likelihood ratio $\chi^{2}$ between Model 2 and Model 1 is highly significant given the difference of 10 degrees of freedom. Thus, our interpretations focus on Model 2. Note that the sample sizes for Asians are much smaller than those for whites and blacks and therefore less likely to generate significant results, but the magnitudes can provide some clues to the relationships between the predictors and the dependent 
variables. For Asians' support for intermarriage with blacks, Model 2 shows that only the dummy variable for 2004 was significant at the 0.05 level, but the magnitudes of odds ratios indicated a lower probability of Asians' support for intermarriage with blacks between 2004 and 2012, but a higher probability of support since 2014, a pattern similar to the one found in the trend analysis. For Asians' support for intermarriage with Hispanics, Model 2 displays no significant coefficient for any of the year dummy variables largely because of the very modest sample size of 428 cases, but the odds ratios revealed a lower likelihood of Asians' support for intermarriage with Hispanics before 2014 and in 2018, but a greater likelihood of support between 2014 and 2016. Finally, Asians in years after 2000 were less likely to support intermarriage with whites than Asians in 2000, although only one year dummy variable for 2012 was statistically significant probably due to the modest sample size.

Table 4. Odds Ratios of Generalized Linear Ordinal Logistic Regression Models Predicting Asians' Support for Intermarriages with Blacks, Hispanics, and Whites, GSS 2000-2018.

\begin{tabular}{|c|c|c|c|c|c|c|}
\hline \multirow{2}{*}{ Predictor } & \multicolumn{2}{|c|}{ Intermarriage with Blacks } & \multicolumn{2}{|c|}{ Intermarriage with Hispanics } & \multicolumn{2}{|c|}{ Intermarriage with Whites } \\
\hline & Model 1 & Model 2 & Model 1 & Model 2 & Model 1 & Model 2 \\
\hline Threshold 1 & $0.054^{* * *}$ & $0.008^{* * *}$ & $0.029 * * *$ & $0.007 * * *$ & $0.014^{* * *}$ & $0.003 * * *$ \\
\hline Threshold 2 & $0.163^{* * *}$ & $0.029 * * *$ & $0.075^{* * *}$ & $0.018^{* * *}$ & $0.037^{* * *}$ & $0.008^{* * *}$ \\
\hline Threshold 3 & $1.972 *$ & 0.460 & 1.277 & 0.402 & 0.788 & 0.208 * \\
\hline Threshold 4 & $5.777^{* * *}$ & 1.378 & $4.131 * * *$ & 1.403 & $2.446^{* *}$ & 0.672 \\
\hline \multicolumn{7}{|l|}{ Year(Ref.=2000) } \\
\hline 2002 & 0.611 & 1.067 & & & 0.775 & 0.703 \\
\hline 2004 & $0.282 *$ & 0.271 * & 0.530 & 0.608 & 0.545 & 0.589 \\
\hline 2006 & 0.604 & 0.737 & 0.471 * & 0.686 & $0.462 *$ & 0.442 \\
\hline 2008 & 0.750 & 0.983 & 0.457 & 0.575 & 0.543 & 0.740 \\
\hline 2010 & 0.425 & 0.508 & 0.424 * & 0.520 & $0.377^{*}$ & 0.426 \\
\hline 2012 & 0.697 & 0.816 & 0.491 & 0.602 & $0.320^{* *}$ & $0.257^{* *}$ \\
\hline 2014 & 1.093 & 1.901 & 0.932 & 1.664 & 0.640 & 0.918 \\
\hline 2016 & 0.928 & 1.270 & 0.909 & 1.203 & 0.810 & 0.971 \\
\hline 2018 & 1.163 & 1.478 & 0.871 & 0.980 & 0.392 & 0.346 \\
\hline Age & & $0.980^{* *}$ & & 0.991 & & 0.993 \\
\hline Female & & 0.962 & & 1.078 & & 0.894 \\
\hline Currently married & & 0.727 & & 0.608 * & & 0.759 \\
\hline \multicolumn{7}{|l|}{ Region $($ Ref. $=$ South) } \\
\hline Northeast & & 1.525 & & 1.357 & & 0.758 \\
\hline Midwest & & 0.784 & & 0.467 * & & $0.313 * *$ \\
\hline West & & $1.786^{*}$ & & 1.447 & & 0.971 \\
\hline Years of schooling & & 0.934 * & & 0.934 & & 0.954 \\
\hline Christian & & 1.571 * & & 1.649 * & & 1.653 * \\
\hline Republican & & 1.580 & & 1.151 & & 1.526 \\
\hline Conservatism & & 0.925 & & 0.960 & & 0.916 \\
\hline \multicolumn{7}{|l|}{ Likelihood ratio } \\
\hline$x^{2}$ & $21 *$ & $70^{* * *}$ & 14 & $53^{* * *}$ & 16 & $55^{* * *}$ \\
\hline $\mathrm{df}$ & 9 & 19 & 8 & 18 & 9 & 19 \\
\hline $\mathrm{N}$ & 479 & 448 & 454 & 428 & 482 & 451 \\
\hline
\end{tabular}

${ }^{*} P \leq 0.05,{ }^{* *} P \leq 0.01,{ }^{* * *} P \leq 0.001$ (one-tailed test).

Table 4 also shows that older Asians were less likely to support intermarriage with any outgroup than younger Asians, but the effect of age was only significant for intermarriage with blacks. The gender difference in Asian's support for intermarriage was not significant at all. However, compared to non-currently married Asians, currently married Asians were significantly less likely to support intermarriage with Hispanics, but not significantly different in support for intermarriage with blacks and whites. Asians in the West were significantly more likely to support intermarriage with blacks than Asians in the South (Model 2), and Asians in the Midwest were significantly less likely to support intermarriage 
with Hispanics and whites than Asians in the South (Model 2). Unexpectedly, education somewhat reduced the likelihood of Asians' support for intermarriage with any group but only significantly for intermarriage with blacks. Asian Christians were more likely to support intermarriages than Asian non-Christians. Party affiliation and ideological orientation made no significant difference in Asians' support for intermarriage with any group.

\subsubsection{Changes in Hispanics' Support for Intermarriage}

Table 5 exhibits the results of three generalized linear ordinal logistic regression models predicting Hispanics' support for intermarriage with blacks, Asians and whites. For support for intermarriage with blacks, the likelihood ratio $\chi^{2}$ is significant for Model 2 but insignificant for Model 1, intimating that Model 2 is a good model, but Model 1 is not. However, none of the covariates in Model 2 is statistically significant at the 0.05 level partly because of the modest sample size. The coefficients for the year dummy variables reveal an up and down pattern over time. For support for intermarriage with Asians, the likelihood ratio $\chi^{2^{\prime}}$ s are not significant for both Models 1 and 2, indicating that neither is a good model since no predictors are significant at the 0.05 level. The coefficients for the year dummy variables display an undulated pattern with a bit more of upswing in the last few years. For support for intermarriage with whites, the likelihood ratio $\chi^{2}$ is significant for Model 1 but not Model 2, suggesting that Model 1 is a better model. The magnitudes of the coefficients for the year dummy variables in Model 1 and Model 2 show that compared to Hispanics in 2000, Hispanics in later years were less likely to support intermarriage with whites. With one exception (i.e., education for support for intermarriage with whites), all covariates are not significant at the 0.05 level, and the directions of the relationships vary without a clear pattern. Hence, the relationships between the covariates and support for intermarriage need further verification by additional research.

Table 5. Odds Ratios of Generalized Linear Ordinal Logistic Regression Models Predicting Hispanics' Support for Intermarriages with Blacks, Asians, and Whites, GSS 2000-2018.

\begin{tabular}{|c|c|c|c|c|c|c|}
\hline \multirow{2}{*}{ Predictor } & \multicolumn{2}{|c|}{ Intermarriage with Blacks } & \multicolumn{2}{|c|}{ Intermarriage with Asians } & \multicolumn{2}{|c|}{ Intermarriage with Whites } \\
\hline & Model 1 & Model 2 & Model 1 & Model 2 & Model 1 & Model 2 \\
\hline Threshold 1 & $0.099 * * *$ & $0.099^{* * *}$ & $0.027^{* * *}$ & $0.030^{* * *}$ & $0.006^{* * *}$ & $0.014^{* * *}$ \\
\hline Threshold 2 & $0.173^{* * *}$ & $0.177^{* *}$ & $0.072^{* * *}$ & $0.090^{* * *}$ & $0.014^{* * *}$ & $0.033^{* * *}$ \\
\hline Threshold 3 & $2.426 *$ & 2.576 & 1.654 & 2.087 & $0.555 *$ & 1.299 \\
\hline Threshold 4 & $5.364^{* * *}$ & $6.005 * *$ & $3.733^{* *}$ & $4.959 *$ & 1.252 & 2.981 \\
\hline \multicolumn{7}{|l|}{ Year $($ Ref. $=2000)$} \\
\hline 2002 & 1.391 & 1.165 & & & 0.715 & 0.696 \\
\hline 2004 & 1.009 & 0.824 & 0.685 & 0.548 & $0.226^{* *}$ & $0.189 * *$ \\
\hline 2006 & 0.948 & 0.710 & 0.776 & 0.634 & $0.283^{* * *}$ & $0.241^{* * *}$ \\
\hline 2008 & 2.107 & 1.846 & 1.382 & 1.196 & 0.647 & 0.642 \\
\hline 2010 & 1.567 & 1.197 & 1.172 & 0.922 & 0.526 & 0.440 * \\
\hline 2012 & 2.102 & 2.006 & 1.298 & 1.061 & 0.550 & $0.453 *$ \\
\hline 2014 & 1.448 & 1.235 & 1.054 & 0.872 & $0.382^{* *}$ & $0.329 * *$ \\
\hline 2016 & 1.622 & 1.495 & 1.244 & 1.137 & 0.559 & 0.543 \\
\hline 2018 & 2.012 & 1.840 & 1.594 & 1.429 & 0.522 & 0.486 \\
\hline Age & & 0.990 & & 0.996 & & 0.998 \\
\hline Female & & 1.271 & & 0.957 & & 1.100 \\
\hline $\begin{array}{l}\text { Currently } \\
\text { married }\end{array}$ & & 0.968 & & 0.962 & & 1.244 \\
\hline \multicolumn{7}{|c|}{ Region (Ref.=South) } \\
\hline Northeast & & 1.594 & & 1.513 & & 1.265 \\
\hline Midwest & & 0.633 & & 0.681 & & 0.706 \\
\hline West & & 1.108 & & 1.098 & & 0.887 \\
\hline Years of schooling & & 1.039 & & 1.030 & & $1.061 *$ \\
\hline Christian & & 1.235 & & 0.989 & & 1.154 \\
\hline Republican & & 0.574 & & 1.075 & & 0.737 \\
\hline Conservatism & & 0.955 & & 1.043 & & 1.041 \\
\hline
\end{tabular}


Table 5. Cont

\begin{tabular}{|c|c|c|c|c|c|c|}
\hline \multirow{2}{*}{ Predictor } & \multicolumn{2}{|c|}{ Intermarriage with Blacks } & \multicolumn{2}{|c|}{ Intermarriage with Asians } & \multicolumn{2}{|c|}{ Intermarriage with Whites } \\
\hline & Model 1 & Model 2 & Model 1 & Model 2 & Model 1 & Model 2 \\
\hline \multicolumn{7}{|c|}{ Likelihood ratio } \\
\hline$x^{2}$ & 15 & $37^{* *}$ & 10 & 18 & $22 * *$ & 26 \\
\hline $\mathrm{df}$ & 9 & 19 & 8 & 18 & 9 & 19 \\
\hline $\mathrm{N}$ & 612 & 566 & 588 & 545 & 614 & 567 \\
\hline
\end{tabular}

\section{Discussion and Conclusions}

In an effort to fill the lacuna in the literature, we have conducted this comparative study of changes in attitudes of whites, blacks, Asians, and Hispanics toward intermarriage with different racial or ethnic groups in the twenty-first century, using the nationally representative samples from GSS 2000-2018. Our trend analyses reveal that whites' support for intermarriage with minorities has generally increased, albeit at a relatively lower level; blacks' support for intermarriage with Asians, Hispanics, and whites has been quite stable at a relatively high level; Asians' and Hispanics' support for intermarriage with other minorities has generally shown an upswing trend with some minor fluctuations, but their support for intermarriage with whites has gone in the opposite direction with oscillations. The results of our generalized linear ordinal logistic regression models show that either including or excluding control variables, whites' attitudes have become generally more supportive of intermarriage with minorities, blacks' support for intermarriage has displayed an undulated pattern, and Asians' and Hispanics' support for intermarriage reveal diverse patterns depending on the group to intermarry with. Largely consistent with our hypothesis, the findings indicate a general trend of narrowing intergroup social distances as well as some increases in social distance between certain groups in the United States in the twenty-first century.

Our findings suggest that in the twenty-first century, the United States has undergone some transformations in intergroup social distance in terms of attitudes toward intermarriage. On the one hand, the social distance between whites and racial or ethnic minorities is narrowing as whites have become increasingly acceptant of, or tolerant toward, intermarriage with all racial or ethnic minorities. On the other hand, minority groups' acceptance of intermarriage has manifested very diverse patterns. Blacks are generally more willing to accept intermarriage with all other groups. Asians have reduced the social distance to blacks and Hispanics in more recent years since 2014 in terms of the acceptance of intermarriage with blacks and Hispanics, but the Asian-white social distance appeared to somewhat increase in light of the acceptance of intermarriage with whites. Similarly, Hispanics may have shortened the social distance to blacks and Asians since 2008 but increased their distance to whites in terms of the acceptance of intermarriage with the respective groups. These mixed patterns indicate both decreasing and increasing intergroup social distance. Overall, social progress has been made, but some uncertainties and challenges remain.

The finding that whites have become more supportive of intermarriage with minority groups is consistent with those in the literature $[10,16,17]$, but our results cover the twentyfirst century and control for other determinants of attitudes toward intermarriage. Our finding of blacks' undulated patterns of support for intermarriage with whites based on multivariate analysis appears to cast some doubts about the results of existing studies mostly based on descriptive or bivariate analyses [3,6,10,17]. We also offer some new information regarding whites' and blacks' support for intermarriage with Asians and Hispanics and Asians' and Hispanics' support for intermarriage with both whites and minority groups.

Additionally, we find varying effects of the control variables on attitudes toward intermarriage across different racial or ethnic groups. Age is inversely correlated with support for intermarriage with all outgroups, albeit significantly only for whites, blacks 
and partly for Asians. Women were more likely to support intermarriage than their male counterparts among whites and blacks with regard to intermarriage with whites. Being Republican and level of political conservatism decreased the probability of support for intermarriage for whites but had no significant effect for minority groups. Education increased the probability of support for intermarriage significantly among whites, had varying effects for Asians and Hispanics, and had no effect for blacks. Regional variations in support for intermarriage were significant for whites, insignificant for Hispanics, and variable in significance for blacks and Asians. Being Christian increased the likelihood of support for intermarriage for blacks and Asians but had no significant impact for whites and Hispanics. Marital status had no effect on support for intermarriage across the board, with one exception, namely, currently married Asians were significantly less likely to support intermarriage with Hispanics than their non-currently married counterparts.

To the best of our knowledge, this is the only study that simultaneously compares attitudes of whites, blacks, Asians, and Hispanics toward intermarriage with multiple outgroups. We conducted this study with national probability samples and generalized linear ordinal logistic models for the twenty-first century. The findings for the white samples and black samples are robust with huge or large sample sizes. However, the sample sizes of the Asian and Hispanic samples are modest, so the results need further substantiation by future research as additional years of GSS or new surveys become available. To be sure, taking a comparative perspective will help gain insights into social distances among racial or ethnic groups in the United States.

It is crucial to note that attitudes toward intermarriage are not tantamount to actual behavior of intermarriage and that there may be some discrepancies between the two. When it comes to intermarriage, people may not do what they say they would do in surveys for social desirability or political correctness. The GSS does not contain any data about actual intermarriages but only provides information about attitudes toward intermarriage. However, data from the U.S. Census Bureau [29] reveal that actual intermarriages have been growing since 1970, especially in the twenty-first century, but the pace has varied, depending on the specific pairing of intermarriage. For example, the number of blackwhite intermarried couples had risen from 65,000 in 1970 to 167,000 in 1980, 211,000 in $1990,363,000$ in 2000, and 558,000 in 2010. The number of intermarried couples between whites and other races (including Asians and Native Americans, but not blacks) had soared from 233,000 in 1970 to 450,000 in 1980, 720,000 in 1990, 1,051,000 in 2000, and 1,723,000 in 2010. The number of intermarried couples between blacks and other races increased with a bit of fluctuation from 12,000 in 1970 to 34,000 in 1980, 33,000 in 1990, 50,000 in 2000, and 132,000 in 2010. The number of Hispanic-non-Hispanic intermarried couples had surged from 584,000 in 1970 to 891,000 in 1980, 1,193,000 in 1990, 1,743,000 in 2000, and $2,289,000$ in 2010. Although the absolute numbers of intermarried couples are useful, it is also important to examine the rates of intermarriage because the absolute numbers are affected by the growing total number of married couples. Our calculation using the data from the U.S. Census Bureau shows that among all married couples, the rate of black-white intermarriage had slowly climbed from $0.15 \%$ in 1970 to $0.34 \%$ in $1980,0.40 \%$ in 1990 , $0.64 \%$ in 2000 , and $0.92 \%$ in 2010 . At no point, the black-white intermarriage rate was over $1 \%$. The rate of intermarriage between whites and other races had significantly risen from $0.52 \%$ in 1970 to $0.91 \%$ in $1980,1.35 \%$ in $1990,1.86 \%$ in 2000 , and $2.85 \%$ in 2010 . The rate of intermarriage between blacks and other races had slightly increased from $0.03 \%$ in 1970 to $0.07 \%$ in $1980,0.06 \%$ in $1990,0.09 \%$ in 2000 , and $0.22 \%$ in 2010 . The rate of intermarriage between Hispanics and non-Hispanics had rapidly increased from $1.31 \%$ in 1970 to $1.79 \%$ in $1980,2.24 \%$ in $1990,3.09 \%$ in 2000 , and $3.79 \%$ in 2010 . In any given year with available data, intra-marriage (e.g., white-white, black-black, Hispanic-Hispanic marriages) remained the dominant marriage pattern. Using data from the 2008-2012 American Community Surveys, Yang and Bohn-Jordan also found that intra-marriage was the predominant pattern of marriage among foreign-born Asians [15]. The above data on actual intermarriages and the data on attitudes toward intermarriages reported in this study indicate that the growing 
acceptance of intermarriage appears to be the common trajectory of both sets of data in the twenty-first century, but the specific patterns vary across racial or ethnic groups and across different pairings of intermarriage. Fully assessing to what extent attitudes toward intermarriage and actual intermarriage behavior are consonant or dissonant is beyond the scope of the current study but will be an interesting topic for future research.

Author Contributions: Both P.Q.Y. and J.P. decided to research changes in American public attitudes toward intermarriage and choose the research design. J.P. performed computer data analysis and drafted the initial paper. P.Q.Y. revised and edited the paper for submission to Societies. In response to the peer reviews, P.Q.Y. shifted the focus of the paper to trends in attitudes of whites, blacks, Asians, and Hispanics toward intermarriage in the twenty-first century; changed the method of data analysis; reran data analyses using the updated data and new samples; rewrote the paper; and completed the final manuscript after found rounds of peer reviews. All authors have read and agreed to the published version of the manuscript.

Funding: This research received no external funding.

Institutional Review Board Statement: Ethical review and approval were waived for this study because it uses public-use data that require no approval.

Informed Consent Statement: Not applicable.

Data Availability Statement: Publicly available datasets were analyzed in this study. This data can be found here: https://gss.norc.org/, accessed on 6 October 2019.

Acknowledgments: An earlier version of this paper was presented at the 114th Annual Meeting of the American Sociological Association in New York, 10-13 August 2019. We appreciate the constructive comments and suggestions of the anonymous reviewers from Societies during the four rounds of review, which have led to this completely new paper.

Conflicts of Interest: The authors declare no conflict of interest.

\section{References}

1. $\quad$ Bogardus, E. A Social Distance Scale. Sociol. Soc. Res. 1933, 3, 265-271.

2. Gordon, M. Assimilation in American Life; Oxford University Press: New York, NY, USA, 1964.

3. Djamba, Y.K.; Kimuna, S.R. Are Americans Really in Favor of Interracial Marriage? A Closer Look at When They Are Asked about Black-White Marriage for Their Relatives. J. Black Stud. 2014, 45, 528-544. [CrossRef]

4. Golebiowska, E. The Contours and Etiology of Whites' Attitudes Toward Black-White Interracial Marriage. J. Black Stud. 2007, 10, 1-23. [CrossRef]

5. Herman, M.R.; Campbell, M.E. I Wouldn't, but You Can: Attitudes Toward Interracial Relationships. Soc. Sci. Res. 2012, 41, 343-358. [CrossRef] [PubMed]

6. Jacobson, C.K.; Johnson, B.R. Interracial Friendship and African American Attitudes about Interracial Marriage. J. Black Stud. 2006, 36, 570-584. [CrossRef]

7. Johnson, B.R.; Jacobson, C.K. Contact in Context: An Examination of Social Settings on Whites' Attitudes toward Interracial Marriage. Soc. Psychol. Q. 2005, 68, 387-399. [CrossRef]

8. Perry, S.L. Religion and Whites' Attitudes toward Interracial Marriage with African Americans, Asians, and Latinos. J. Sci. Study Relig. 2013, 52, 425-442. [CrossRef]

9. Wilson, D.; Jacobson, C. White attitudes toward black and white interracial marriage. In American Families: Issues in Race and Ethnicity; Jacobson, C., Ed.; Garland: New York, NY, USA, 1995; pp. 353-367.

10. Carroll, J. Most Americans Approve of Interracial Marriages: Blacks More Likely Than Whites to Approve of Black-White Unions. Gallup News Services. 2007. Available online: https://news.gallup.com/poll/28417/most-americans-approve-interracialmarriages.aspx (accessed on 6 October 2019).

11. Livingston, G.; Brown, A. Intermarriage in the U.S. 50 Years after Loving v. Virginia; Pew Research Center: Washington, DC, USA, 2017. Available online: https:/ / www.pewsocialtrends.org/2017/05/18/intermarriage-in-the-u-s-50-years-after-loving-v-virginia / (accessed on 6 October 2019).

12. Passel, J.S.; Wang, W.; Taylor, P. Marrying Out: One-in-Seven New U.S. Marriages Is Interracial or Interethnic; Pew Research Center: Washington, DC, USA, 2010. Available online: https:/ /www.pewsocialtrends.org/2010/06/04/marrying-out/ (accessed on 6 October 2019).

13. Wang, W. The Rise of Intermarriage: Rates, Characteristics Vary by Race and Gender. In Social and Demographic Trends; Pew Research Center: Washington, DC, USA, 2012. Available online: http://www.pewsocialtrends.org/2012/02/16/chapter-4public-attitudes-on-intermarriage/ (accessed on 5 October 2019). 
14. Spickard, P. Mixed Blood: Intermarriage and Ethnic Identity in Twentieth Century America; University of Wisconsin Press: Madison, WI, USA, 1989.

15. Yang, P.Q.; Bohm-Jordan, M. Patterns of Interracial and Interethnic Marriages among Foreign-Born Asians in the United States. Societies 2018, 8, 87. [CrossRef]

16. Schuman, H.; Steeh, C.; Bobo, L.; Krysan, M. Racial Attitudes in America: Trends and Interpretations; Revised edition; Harvard University Press: Cambridge, MA, USA, 1997.

17. Jones, J.M. Record-High 86\% Approve of Black-White Marriages: Ninety-Six Percent of Blacks, $84 \%$ of Whites Approve. Gallup News Services. 2011. Available online: https:/ / news.gallup.com/poll/149390/record-high-approve-black-white-marriages.aspx (accessed on 6 October 2019).

18. Yancey, G.; Lewis, R. Interracial Families: Current Concepts and Controversies; Routledge: New York, NY, USA, 2009.

19. Batson, C.D.; Qian, Z.; Lichter, D.T. Interracial and Intraracial Patterns of Mate Selection Among America's Diverse Black Populations. J. Marriage Fam. 2006, 68, 658-672. [CrossRef]

20. Qian, Z. Breaking the Racial Barriers: Variations in Interracial Marriage between 1980 and 1990. Demography 1997, 34, 478-500. [CrossRef]

21. Qian, Z.; Lichter, D.T. Social Boundaries and Marital Assimilation: Interpreting Trends in Racial and Ethnic Intermarriage. Am. Sociol. Rev. 2007, 72, 68-94. [CrossRef]

22. Rosenfeld, M.J. A Critique of Exchange Theory in Mate Selection. Am. J. Sociol. 2005, 110, 1284-1325. [CrossRef]

23. Qian, Z.; Cobas, J.A. Latinos' Mate Selection: Variations by National Origin, Race, and Nativity. Soc. Sci. Res. 2004, 33, 225-247. [CrossRef]

24. Allport, G. The Nature of Prejudice; Addison-Wesley: Reading, MA, USA, 1954.

25. Lichterman, P.; Carter, P.; Lamont, M. Race-Bridging for Chris? Conservative christians and black-white relations in community life. In Evangelicals and Democracy in America; Brint, S., Schroedel, J., Eds.; Russell Sage: New York, NY, USA, 2009; Volume 1, pp. 187-220.

26. Yancey, G. An Examination of the Effects of Residential and Church Integration on Racial Attitudes of Whites. Sociol. Perspect. 1999, 42, 279-304. [CrossRef]

27. Yang, P.Q. Asian Immigration to the United States; Polity: Cambridge, UK, 2011.

28. Smith, T.; Davern, M.; Freese, J.; Hout, M. General Social Surveys, 1972-2018; NORC: Chicago, IL, USA, 2019.

29. U.S. Census Bureau. Interracially Married Couples by Race and Hispanic Origin of Spouses. Available online: https://www2 .census.gov/library/publications/2011/compendia/statab/131ed/tables/12s0060.xls (accessed on 4 March 2021). 